\title{
Economic Valuation of Coastal and Marine Resources: Bohol Marine Triangle, Philippines
}

\author{
GISELLE P. B. SAMONTE-TAN \\ Faculty of Management and Development Studies \\ University of the Philippines Open University \\ Los Baños, Laguna, Philippines
}

\begin{abstract}
ALAN T. WHITE
Fisheries Improved for Sustainable Harvests (FISH) Project of Tetra Tech EMI and the Coastal Conservation and Education Foundation, Inc.

Cebu City, Philippines
\end{abstract}

\section{MARY ANN TERCERO JOHN DIVIVA}

$\mathrm{UNDP} / \mathrm{GEF} /$

Foundation for the Philippine Environment Bohol Marine Triangle Project

Bohol, Philippines

\section{ESPERANZA TABARA CIEMON CABALLES}

Coastal Conservation and Education (CCE) Foundation, Inc. Banilad Cebu City, Philippines

\begin{abstract}
This article provides results on the net benefits generated from the natural resources in the Bohol Marine Triangle (BMT) in the Philippines. The BMT spans over 112,000 ha and its coastal ecosystems are rich in biodiversity and provide economic opportunities to the coastal communities. With a $10 \%$ discount rate, the accumulated total net benefits for the BMT resources over a 10-year period is US\$11.54 million. Tourism
\end{abstract}

This study was supported by a grant from the Bohol Marine Triangle Project of the Foundation for the Philippine Environment supported by the United Nations Development Programme-Global Environment Facility to the Coastal Conservation and Education Foundation, Inc. The Local Government Units of the Municipalities of Baclayon, Dauis and Panglao, as well as the Bohol Alliance of Non-Government Organizations are gratefully acknowledged for their support in the conduct of the study. Provincial Offices of Bureau of Fisheries and Aquatic Resources, Bohol Environment Management Office and the Bureau of Agricultural Statistics are acknowledged for the data provided. Much appreciation is extended to all the participants of the stakeholder consultation workshops for their valuable inputs. We thank Rafael Martinez for preparing the maps.

Address correspondence to Giselle PB. Samonte-Tan, Affiliate Faculty, Faculty of Management and Development Studies, University of the Philippines Open University, Los Baños, Laguna 4031, Philippines. E-mail: samonte_g@yahoo.com 
and the municipal fisheries are the most important direct use values of the coastal and marine resources of the BMT accounting for $44 \%$ and $39 \%$ of the total net benefits. Annual revenues attributed to ecosystems were as follows: coral reefs, US $\$ 1.26$ million; beach/intertidal area, US $\$ 1.12$ million; marine waters, US $\$ 646,501$; mangrove, US $\$ 239,561$; and seagrass, US\$105,990. The large market values indicate the dependence of the local community on the BMT coastal and marine resources. In the same way, non-market values show the important life-support functions of coastal and marine ecosystems. The net benefits reflect the magnitude of potential losses due to improper management of coastal and marine resources in the BMT. This valuation highlights the importance of the coastal services to the BMT economy and draws attention to the benefits the local stakeholders derive from BMT coastal resources. Policy measures can now take into account these values to justify a sufficient investment in coastal management efforts to sustain the flow of coastal services in the interest of current and future generations.

Keywords benefits of coastal resources, direct use values, economic valuation, resource management

\section{Introduction}

The Bohol Marine Triangle (BMT) spans over 112,000 ha and includes the three islands of Panglao (9,000 ha), Pamilacan (200 ha) and Balicasag (25 ha) in three municipalities of Baclayon, Dauis, and Panglao (Figure 1). The BMT area is significant in terms of biodiversity including: eleven of the 22 species of marine mammals in the Philippines; three of the world's eight species of sea turtles; rare and endangered species of pelagic fishes (whale sharks, mantas and stingrays), seahorses and giant clams; rare shells such

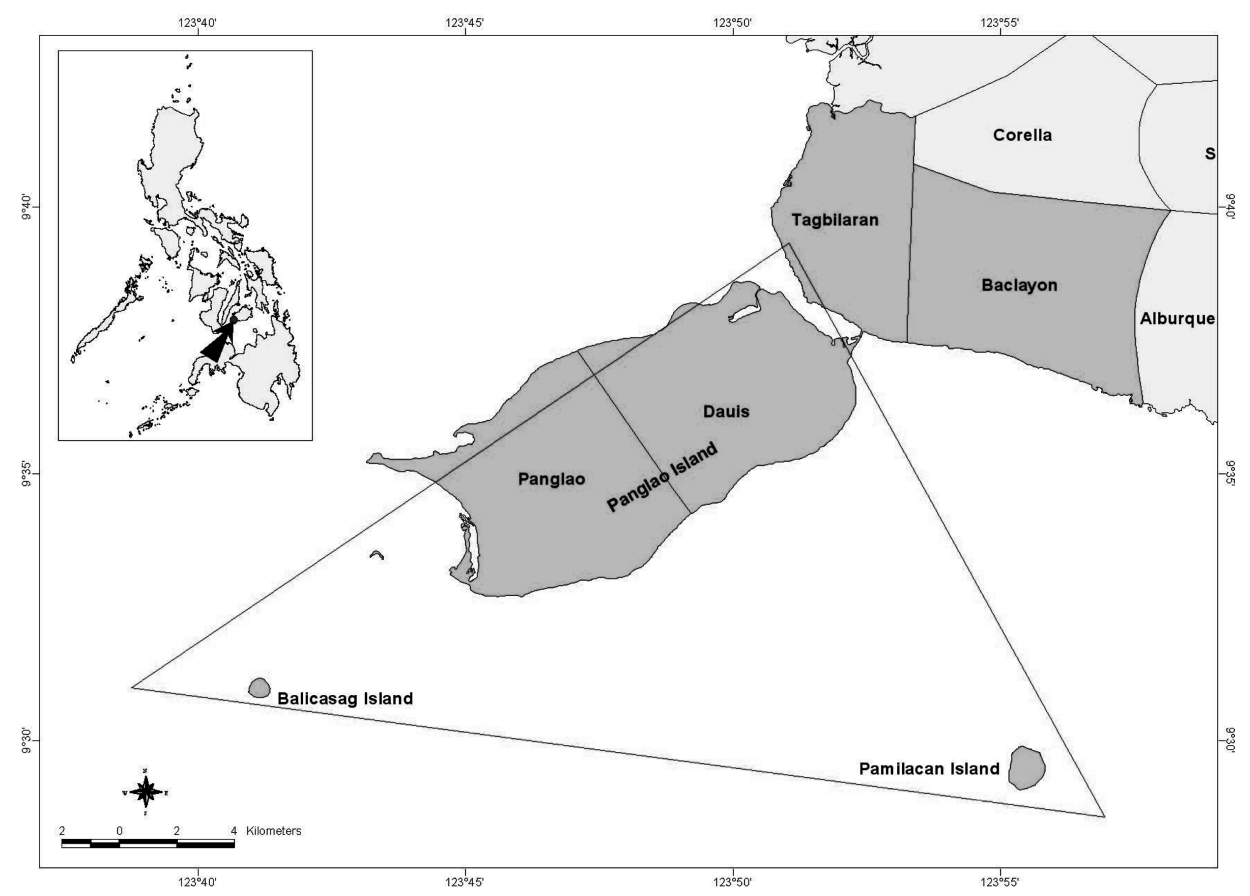

Figure 1. Bohol Marine Triangle, Bohol Province, Philippines (source: Profile of the BMT, 2004). 
as Conus gloriamaris, Cypraea guttata and Cypraea valentia and several migratory birds. In addition, the coastal ecosystems of the BMT are productive and provide economic opportunities to coastal communities.

Although key interventions ${ }^{1}$ by the local government units and non-government organizations have been initiated to conserve biodiversity resources, the net benefits generated from the rich and diverse coastal ecosystems of the BMT have not been considered in decision-making. In addition, environmental and socioeconomic issues have recently been identified by the local stakeholders, ${ }^{2}$ thus motivating the need for the economic valuation as a basis for understanding and developing appropriate economic instruments for sustaining the use of the BMT resources. Putting monetary value is one way of enhancing the knowledge of stakeholders in recognizing the importance of coastal and marine resources to economic development on a sustainable and ecologically sound basis. This study provides information on the net benefits generated from coastal habitats and ecosystems in terms of direct production from fisheries, gleaning, seaweed farming, tourism, research and education uses for three municipalities of Baclayon, Dauis, and Panglao.

\section{Coastal and Marine Resources}

The four ecosystems identified in this study included coral reefs and their associated habitats (seagrass, Sargassum, etc.), mangroves, beaches or intertidal areas, and marine waters (Figure 2). The BMT has 554 ha of coral reef area (Table 1) with 263 hard coral species. Hard coral cover ranged from $9.5-21 \%$ in 1984 and increased to $20.4-68.3 \%$ in 2003 (Calumpong, 2004; White, et al., 2003). The increase in hard coral cover can be attributed to the conservation efforts of the local government units and non-government

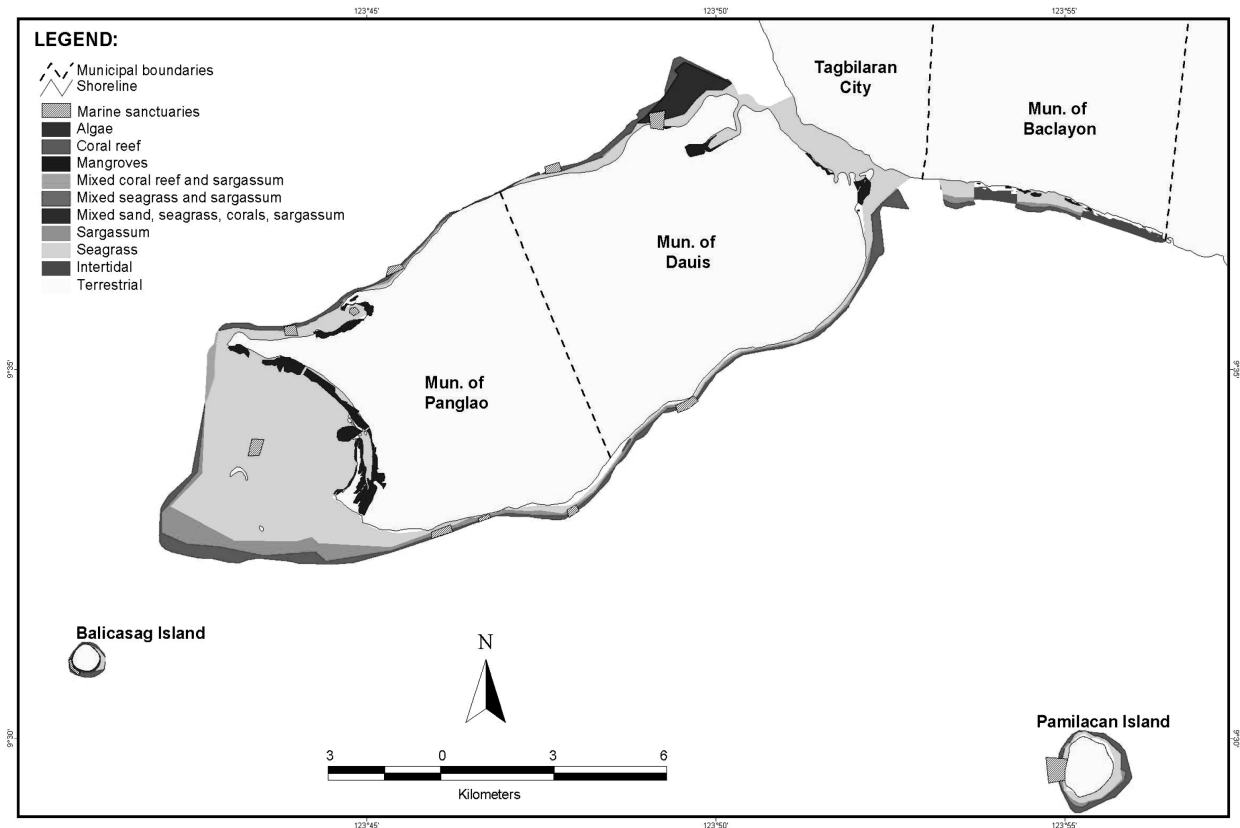

Figure 2. BMT coastal and marine ecosystems. (source: Profile of the BMT, 2004). 
Table 1

Area of coastal and marine ecosystems

\begin{tabular}{lccrrr}
\hline & & \multicolumn{3}{c}{ Area of major ecosystems (ha) } \\
\cline { 3 - 6 } Municipality & $(\mathrm{km})$ & Coral Reefs & Mangroves & Seagrass & Sargassum \\
\hline Baclayon & 7 & 91.90 & 8.80 & 137.30 & 41.00 \\
Dauis & 23 & 174.36 & 43.35 & 490.58 & 48.13 \\
Panglao & 25 & 287.80 & 200.38 & $1,928.00$ & 319.00 \\
Total BMT & 55 & 554.06 & 252.53 & $2,555.88$ & 408.13 \\
\hline
\end{tabular}

organizations (NGOs) such as the establishment of marine protected areas (MPAs). All reef fishes and target fishes inside the reserves are also predominantly stable and showed an increase in density. Mean fish density of all reef fish species in the reserve and non-reserve areas was 2777 individuals $/ 500 \mathrm{~m}^{2}$ and 2578 individuals $/ 500 \mathrm{~m}^{2}$, respectively (Calumpong, 2004). Mean fish density of all target species was 232 individuals $/ 500 \mathrm{~m}^{2}$ in reserve areas and 157 individuals $/ 500 \mathrm{~m}^{2}$ in non-reserve areas (Calumpong, 2004).

Of the 35 recorded mangrove species in the Philippines, 30 species covering 253 ha are found in the BMT area. The BMT has 2556 ha of seagrass beds with 9 species of the 16 species of seagrasses identified in Philippine waters. The BMT area has 131 species of algae covering 408 ha. The BMT area spans over 112,000 ha, $92 \%$ of which is deep-sea or marine water. This area, which ranges from 32 to 357 meters deep, provides a migratory route for whales and dolphins (Figure 3 ) as well as habitat of these species and other marine life (Foundation for Philippine Environment, 2000).

Table 2 presents the threats to these resources, which include habitat destruction, damage to coral reefs from tourist activities, unsustainable harvesting levels of fish and shells and potential impacts of pollution (CCEFI, 2004).

\section{Valuation Method}

The annual net benefits generated from coastal and marine ecosystem is the sum of all net benefits from use and non-use values. Use value measures the consumptive value or direct use values of tangible natural resources, and non-consumptive or indirect use values. Direct use values can be extractive such as net revenues from the fishery, and non-extractive such as tourism. Indirect use values are the functional benefits derived from the resources such as coastline protection and habitat for fish and shellfish.

Non-use values consist of option value, bequest value and existence value. Option value is the potential direct and indirect use of the ecosystem and resources. Option value reflects the value of natural resources for future generations. Existence value is the value a person puts on the resource for knowing that a resource exists and being protected. Bequest value is the value of leaving or endowing a natural resource to the next generation.

The annual net benefits are computed using the total economic value (TEV) framework (Spurgeon, 1992) as follows:

$$
\mathrm{TEV}=\text { use value }+ \text { non-use value }=(\mathrm{DUV}+\mathrm{IUV}+\mathrm{OV})+(\mathrm{XV}+\mathrm{BV})
$$

where, $\mathrm{DUV}=$ direct use value, IUV $=$ indirect use value, $\mathrm{OV}=$ option value, $\mathrm{XV}=$ existence value, $\mathrm{BV}=$ bequest value. 


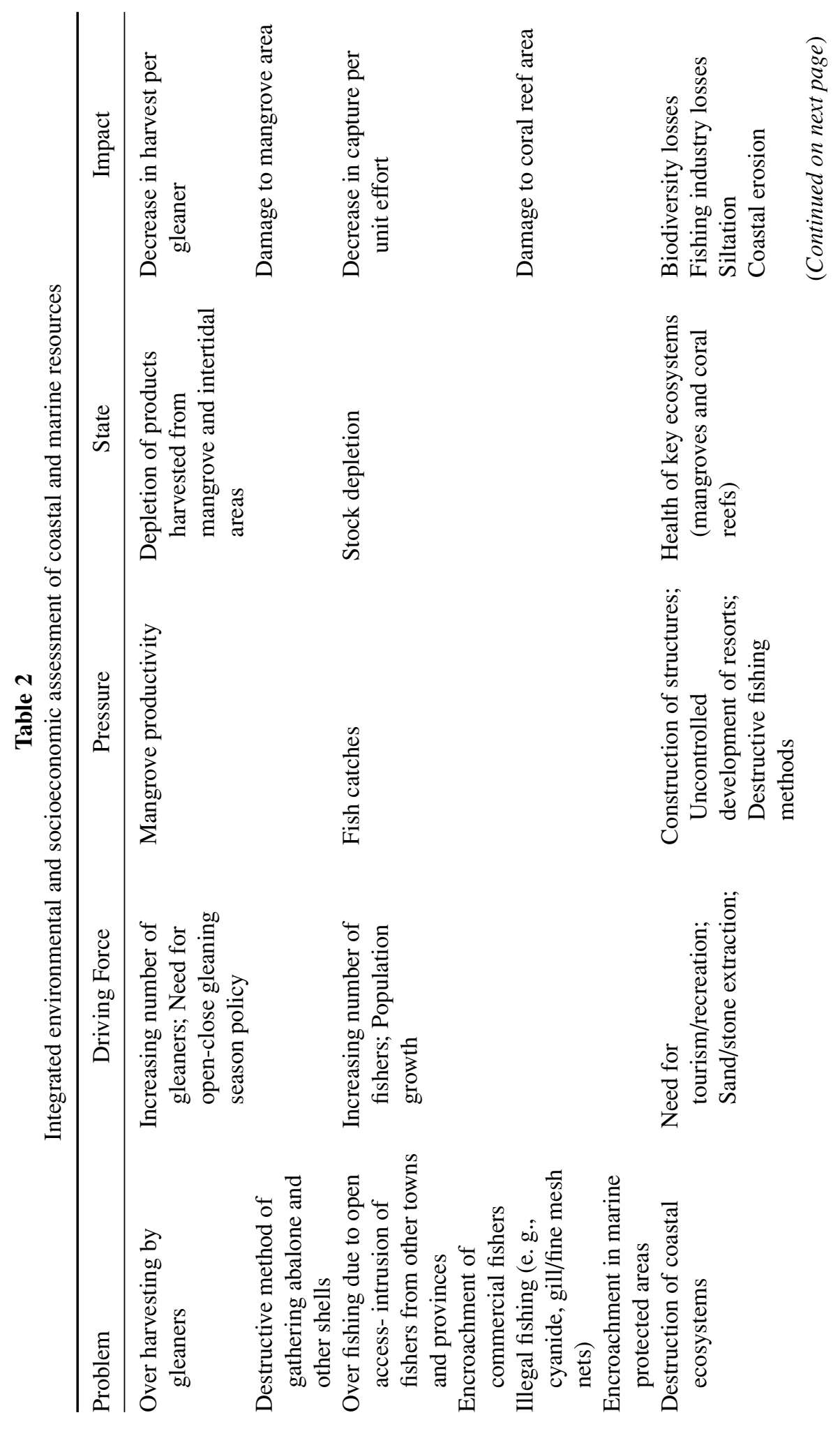




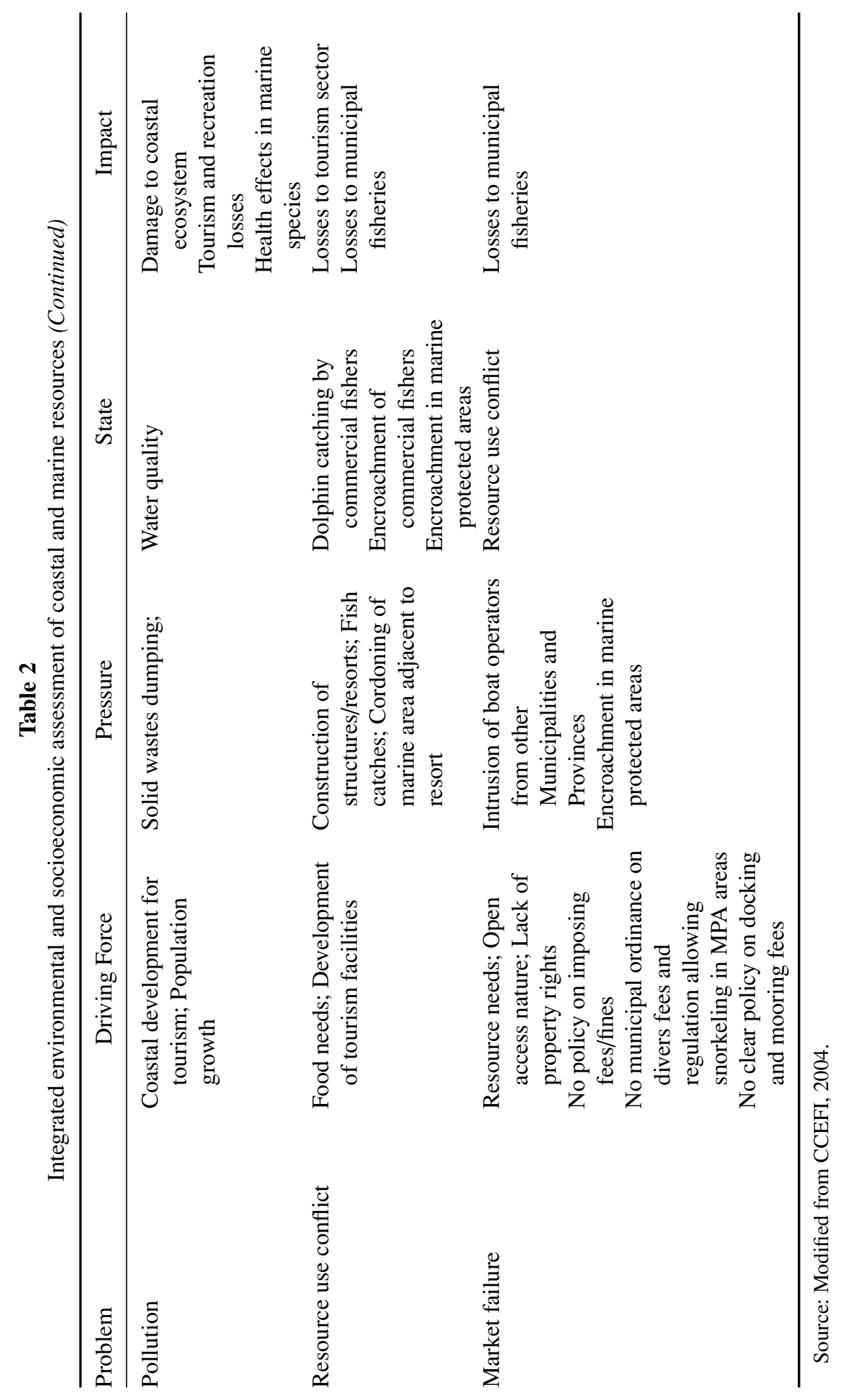




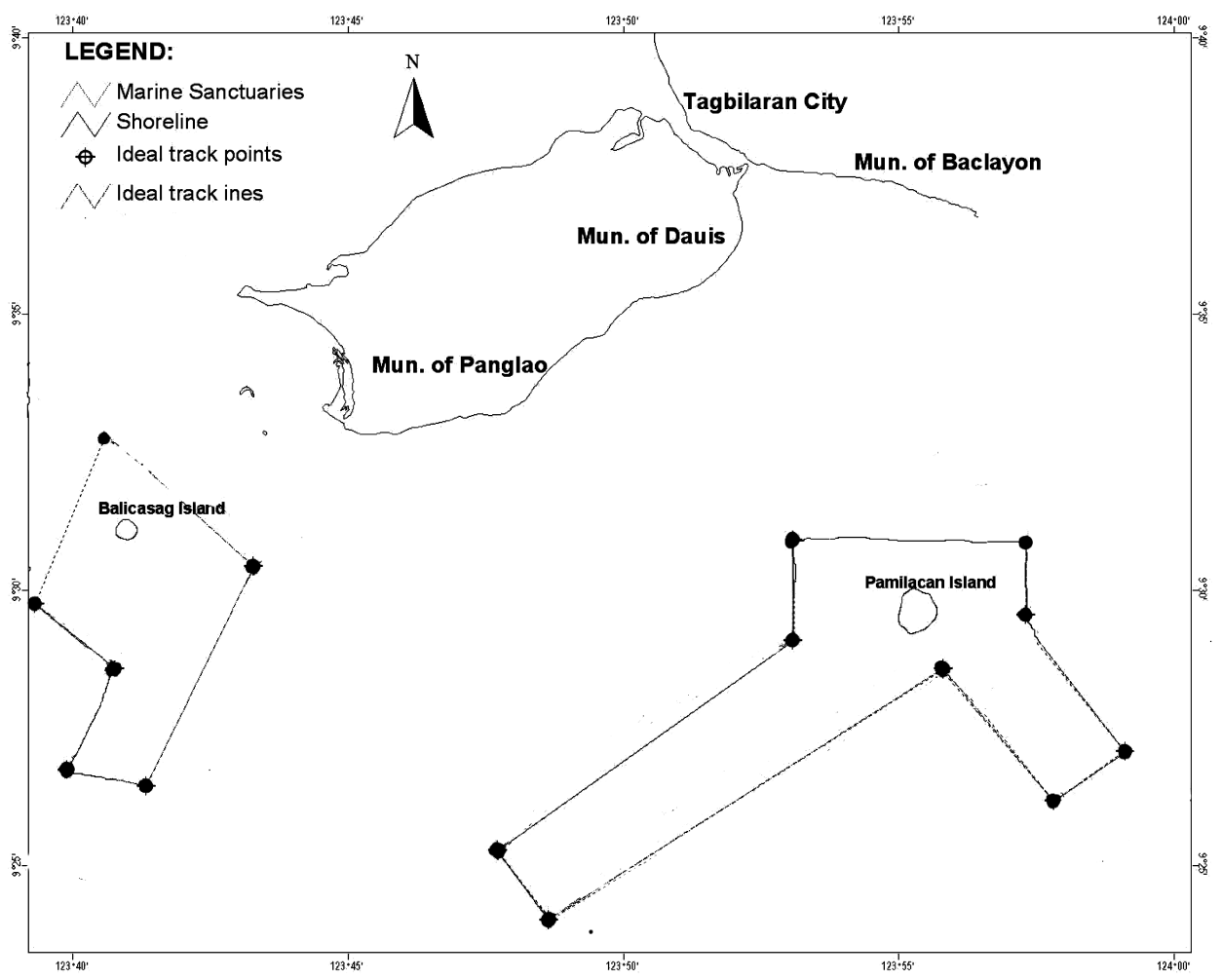

Figure 3. Dolphin and whale tract lines in the Bohol Marine Triangle Area (source: Profile of the BMT, 2004).

Table 3 shows the major economic uses of the coastal and marine resources in the Bohol Marine Triangle. The resource uses were verified through key informant interviews in June 2004 with the Mayor of Baclayon, Municipal Planning Development Officers of Dauis and Panglao, Municipal Agricultural Officers, Fisheries Technicians, barangay or village captains, and during the stakeholders' consultation workshop in September 2004. Relevant information on the status and uses of marine ecosystems were provided by various provincial agency offices, including the Bureau of Fisheries and Aquatic Resources (BFAR), Bohol Environmental Management Office (BEMO), and the Bureau of Agricultural Statistics (BAS).

A survey was conducted in August 2004 in the three municipalities of Baclayon, Dauis and Panglao. A total of 233 resource users were interviewed using a pre-tested questionnaire. Surveyed user groups included municipal fishers $(n=147)$, gleaners $(n=$ $32)$, seaweed farmers $(n=28)$, and tourism business operators $(n=20)$.

The benefits transfer method, ${ }^{3}$ wherein the values derived in various studies are transferred and adjusted, was used to estimate non-marketed benefits. If a study has been carried out in other, comparable areas, then it is likely that these values can form a proxy for another area (Cesar \& Chong, 2004). The benefit transfer approach estimates the net benefits of a similar environmental impact from an existing study, and transfers it to a new context, assuming that the existing value can be used as an approximation. The following steps were undertaken in applying the benefit transfer method: (1) identification of existing 
Table 3

Major uses of coastal and marine resources

\begin{tabular}{|c|c|c|}
\hline \multirow[b]{2}{*}{ Location/Habitat } & \multicolumn{2}{|c|}{ Use values } \\
\hline & Direct & Indirect \\
\hline Coral reefs & $\begin{array}{l}\text { Fisheries Tourism-diving, } \\
\text { snorkeling Research }\end{array}$ & Shoreline protection \\
\hline Mangroves & $\begin{array}{l}\text { Fish } \\
\text { Mollusc }\end{array}$ & $\begin{array}{l}\text { Nursery for fish/mollusc } \\
\text { Shoreline protection }\end{array}$ \\
\hline Seagrass/Sargassum & Eucheuma sp. farming & \\
\hline Beaches & $\begin{array}{l}\text { Tourism—picnic, bird } \\
\text { watching }\end{array}$ & \\
\hline Marine waters & $\begin{array}{l}\text { Fisheries } \\
\text { Tourism—dolphin/whale } \\
\text { watching }\end{array}$ & \\
\hline
\end{tabular}

studies where the benefit has been estimated; (2) identification of the relevant values to be applied; (3) substitution of the values to calculate the benefits; (4) calculation of the total discounted value.

Producer surplus was computed for coastal and marine-based economic sectors (i.e., fishery, mariculture, tourism). Producer surplus is the excess of the revenue over costs received by resource users (i.e., fishers, gleaners, seaweed farmers, tourism business operators). Costs represent the minimum amount a resource user would be willing to accept to maintain his current effort/operation level. Gross revenue included the value of products (fish, shellfish, seaweed) and services (tourism operations) generated from the economic activity. Total cost consisted of variable costs (fuel, supplies, repair, packing cost, labor shares) and fixed costs (depreciation of vessel, repair and maintenance). Data on costs and revenues were obtained by interviewing fishers $(n=242)$, gleaners $(n=74)$, seaweed farmers $(n=42)$, and tourism entrepreneurs $(n=38)$ using a pre-tested questionnaire from June to July 2004. The net revenue for the $i^{\text {th }}$ economic sector $\left(R_{i}\right)$, gross revenue $(G R)$, and total cost (TC) are calculated, respectively:

$$
\begin{aligned}
\mathrm{NR}_{\mathrm{i}} & =\mathrm{GR}-\mathrm{TC} \\
\mathrm{GR}_{\mathrm{i}} & =\mathrm{Q}_{\mathrm{i}} \mathrm{P}_{\mathrm{i}} \\
\mathrm{TC} & =\mathrm{VC}+\mathrm{FC}
\end{aligned}
$$

where, Q is quantity of produced, $\mathrm{P}$ is ex-vessel or farm-gate price, VC is total variable cost and FC is fixed cost.

As natural assets, coral reefs provide a stream of valuable services to society over time. Economic benefits derived from BMT coastal and marine resources were calculated as the sum of the present value of the stream of revenues (NPV) over a 20-year period as follows:

$$
\mathrm{NPV}=\left(\sum_{T}^{T 1} B i-\sum_{T}^{T 1} C i\right) /(1+r)^{t}
$$


where, $N P V=$ net present value, $B=$ benefits, $C=$ costs, $i=$ coastal and marine-based economic activities, $t=$ year, $r=$ social discount rate.

\section{Results}

\section{Coastal Population and Resource Users}

In 2,000, the BMT area supported a population of 49,500 individuals or 9,500 households. This reflects a $12.8 \%$ increase in BMT population over the 1995 population of 43,900 . With land area pegged at $89.6 \mathrm{~km}^{2}$, the population density was 552 individuals $/ \mathrm{km}^{2}$ in 2000 . This density is higher than the Philippine national average of 255 individuals $/ \mathrm{km}^{2}$ and the coastal average of 239 individuals $/ \mathrm{km}^{2}$ (NSCB, 2003). Of the total households in the BMT, 39.3\% have at least one household member engaged in a marine-based livelihood that relies on the coastal and marine resources of the BMT. These resource users include municipal fishers ${ }^{4}$ who comprise $78.5 \%$ of the total resource users, gleaners $(17.1 \%)$, seaweed farmers $(2.7 \%)$ and operators of tourism-related activities (1.8\%). Tourism-related users include operators of resorts/hotels, dive shops, restaurants, and boat service for whale/dolphin tours.

Table 4 shows the socio-economic profile of municipal fishers, gleaners, seaweed farmers, and operators of tourism-related businesses. Resource users are mostly in their late forties. Except for tourism business operators, the fishers, gleaners and seaweed farmers are residents of the barangay or villages since birth or an average of 38 years. Operators of tourism businesses have resided in the BMT for less than 13 years. This implies that tourism business operators are not originally from the BMT area and have migrated from other areas. The average household size is six. Operators of tourism businesses have completed college degrees compared with the other user groups who completed only elementary level education. Income is higher for those in the engaged in tourism activities. Average monthly income from fishing was US $\$ 81 .^{5}$ Gleaning activity generated average monthly income of ranging from US $\$ 13-16$. Income from seaweed farming ranged from US $\$ 52-96$ per month. Monthly tourism revenue was US $\$ 307$ for boat tour service, US $\$ 2,090-2,907$ for hotel/resort, and US $\$ 2998$ for dive shop. Land-based occupations to supplement their income include processing/drying of fish products, employee, laborer, farming, livestock raising, and other small business. The average monthly income from land-based livelihood ranged from US $\$ 26$ (farming) to US $\$ 1026$ (livestock raising). Community organizations exist for all user groups. For seaweed farming and tourism business, the majority are members of the local organization/association.

\section{Net Benefits Generated from the Bohol Marine Triangle}

Revenue from fishing. The municipal waters in the BMT are used for traditional fishing grounds. Municipal fishers are dependent on the various reef areas for fish food (subsistence) and commercial exchange. Common fishing gears used are the hook and line, nets, spear and fish trap. Peak fishing months are from April to June. From a total of 242 fishers surveyed, the average fish yield ${ }^{6}$ ranged from 4.7-12.5 kg/trip during peak months and as low as 1.4-3.5 kg/trip during lean months. Related costs recorded from the fishers' survey included fuel, ice and salt, maintenance and repair, labor ${ }^{7}$ and other miscellaneous expenses. Depending on the location of fishing ground, the annual net revenue per fisher ranged from US $\$ 333$ (mangrove area) to US $\$ 1355$ (coral reef area). Net revenue from municipal fishing comprised $70-90 \%$ of gross revenue. For each municipality, the annual 
Table 4

Socioeconomic profile of coastal and marine resource users, BMT

\begin{tabular}{|c|c|c|c|c|c|}
\hline \multicolumn{2}{|c|}{ Socioeconomic profile } & \multirow{2}{*}{$\begin{array}{c}\begin{array}{c}\text { Fishers } \\
\mathrm{n}=242\end{array} \\
97.9 \%\end{array}$} & \multirow{2}{*}{$\begin{array}{c}\text { Gleaners } \\
n=74 \\
15.6 \%\end{array}$} & \multirow{2}{*}{ 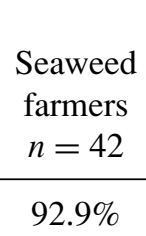 } & \multirow{2}{*}{$\begin{array}{c}\begin{array}{c}\text { Tourism } \\
\text { business } \\
\text { operators } \\
n=38\end{array} \\
36.8 \%\end{array}$} \\
\hline 1. Gender & $\%$ Male & & & & \\
\hline & $\%$ Female & $2.1 \%$ & $84.4 \%$ & $7.1 \%$ & $63.2 \%$ \\
\hline \multirow[t]{3}{*}{ 2. Age } & Minimum & 22 & 28 & 29 & 23 \\
\hline & Maximum & 79 & 76 & 71 & 54 \\
\hline & Average & 46 & 45 & 52 & 37 \\
\hline \multirow[t]{3}{*}{ 3. Civil status } & $\%$ Single & $14.4 \%$ & $6.3 \%$ & $7.1 \%$ & $36.8 \%$ \\
\hline & $\%$ Married & $84.2 \%$ & $93.8 \%$ & $92.9 \%$ & $57.9 \%$ \\
\hline & $\%$ Others $^{\mathrm{a}}$ & $1.4 \%$ & & & $5.3 \%$ \\
\hline \multirow{3}{*}{$\begin{array}{l}\text { 4. Number of years } \\
\text { living in village }\end{array}$} & Minimum & 1 & 3 & 4 & 1 \\
\hline & Maximum & 79 & 76 & 64 & 45 \\
\hline & Average & 38 & 39 & 42 & 13 \\
\hline \multirow{3}{*}{$\begin{array}{l}\text { 5. No. of people } \\
\text { living in } \\
\text { household }\end{array}$} & Minimum & 1 & 1 & 1 & 1 \\
\hline & Maximum & 16 & 8 & 14 & 8 \\
\hline & Average & 6 & 5 & 6 & 4 \\
\hline \multirow{2}{*}{$\begin{array}{l}\text { 6. Monthly income } \\
\text { from fishing }\end{array}$} & Average $\mathrm{PhP} /$ month & 4,190 & 1,217 & 6,014 & 16,563 \\
\hline & US\$ & 78 & 23 & 111 & 307 \\
\hline \multirow{2}{*}{$\begin{array}{l}\text { 7. Monthly income } \\
\text { from other } \\
\text { occupation }^{\mathrm{b}}\end{array}$} & Average $\mathrm{PhP} /$ month & 2,418 & 2,623 & 2,974 & 143,913 \\
\hline & US\$ & 45 & 49 & 55 & 2,665 \\
\hline \multirow{2}{*}{$\begin{array}{l}\text { 8. Member of } \\
\text { organization }\end{array}$} & $\%$ Yes & $57.10 \%$ & $59.40 \%$ & $82.10 \%$ & $68.40 \%$ \\
\hline & $\%$ No & $42.90 \%$ & $40.60 \%$ & $17.90 \%$ & $31.60 \%$ \\
\hline \multirow[t]{8}{*}{ 9. Education } & $\%$ No Education & $0.00 \%$ & $0.00 \%$ & $0.00 \%$ & $0.00 \%$ \\
\hline & $\%$ Elementary Level & $26.00 \%$ & $18.80 \%$ & $3.60 \%$ & $0.00 \%$ \\
\hline & \%Elementary Grad. & $51.40 \%$ & $37.50 \%$ & $35.70 \%$ & $0.00 \%$ \\
\hline & \%High Sch. Level & $11.00 \%$ & $12.50 \%$ & $14.30 \%$ & $0.00 \%$ \\
\hline & \%High Sch. Grad. & $7.50 \%$ & $21.90 \%$ & $25.00 \%$ & $10.50 \%$ \\
\hline & $\%$ Vocational & $0.70 \%$ & $6.30 \%$ & $7.10 \%$ & $10.50 \%$ \\
\hline & $\%$ College Level & $2.70 \%$ & $3.10 \%$ & $7.10 \%$ & $15.80 \%$ \\
\hline & \%College Grad. & $0.70 \%$ & $0.00 \%$ & $7.10 \%$ & $63.20 \%$ \\
\hline
\end{tabular}

${ }^{a}$ Separated, widowed.

${ }^{b} 1$ USD $=54$ Philippine pesos (2004).

net revenue per fisher was multiplied by the total number of fishers. Overall, the annual net benefits generated from municipal fisheries was US $\$ 1.33$ million.

Revenue from gleaning. Coastal residents also gather/glean gastropods, bivalves and echinoderms especially during low tide. ${ }^{8}$ From a total of 74 gleaners surveyed, the quantity gleaned ranged from $0.5 \mathrm{~kg}-5 \mathrm{~kg}$ per day and these are placed in plastic pails, baskets or bottles. In Baclayon, gleaned species are for consumption. In Dauis, echinoderms are harvested mainly for consumption while mollusks are sold at US\$0.09-0.56/container. In Panglao, 
Table 5

Number of tourists, 2003

\begin{tabular}{lccc}
\hline & \multicolumn{2}{c}{ Monthly tourists } & \\
\cline { 2 - 3 } Municipality & Peak months $^{b}$ & Lean months $^{c}$ & BMT tourists per year \\
\hline Baclayon $^{a}$ & 495 & 128 & 3,738 \\
Dauis & 1,875 & 906 & 16,686 \\
Panglao & 3,136 & 1,454 & 27,540 \\
Total & 5,506 & 2,488 & 47,964 \\
\hline
\end{tabular}

${ }^{a}$ Pamilacan Island Dolphin and Whale Watching Organization (PIDWWO).

${ }^{b}$ Peak months from December to May.

${ }^{c}$ Lean months from June to November.

harvested mollusks and echinoderms are sold at US $\$ 0.56-3 / \mathrm{kg}$ and US $\$ 0.37-0.74 /$ bottle. Average annual net revenue per gleaner ranges from US $\$ 115$ to US $\$ 511$. For each municipality, the annual net revenue per gleaner was multiplied by the total number of gleaners. The annual net benefit from gleaning is US $\$ 166564$.

Revenue from seaweed farming. Seaweed farming in Dauis and Panglao is another marine-based activity, which local residents have engaged in through their local seaweed organizations. ${ }^{9}$ Monoline is the culture method adopted by seaweed farmers. Peak months given by the seaweed farmers are from April to June while the rest of the months are considered lean months because of monsoon winds. Farm size ranges from 1034 $\mathrm{m}^{2}-3650 \mathrm{~m}^{2}$. Seaweed species cultured is Kappaphycus alvarezii and Eucheuma sp. Culture period is 45 days. With two crops per year, the annual yield is $40.6 \mathrm{~kg} / \mathrm{m}^{2}-67.56 \mathrm{~kg} / \mathrm{m}^{2}$. Farm-gate price is US $\$ 0.06$-US $\$ 0.15 / \mathrm{kg}$ for fresh seaweed and US $\$ 0.65-\mathrm{US} \$ 1.5 / \mathrm{kg}$ for dried seaweed. The average net revenue obtained from a survey of 42 seaweed farmers is US $\$ 79 /$ crop-US $\$ 144 /$ crop. Annual net revenue is US $\$ 157-U S \$ 288$. This value was multiplied by the total number of seaweed farmers in the BMT to arrive at annual net benefits of US $\$ 23087$ for the BMT area.

Tourism revenue. Tourism activities in the BMT are mainly scuba diving, whale and dolphin watching, swimming, snorkeling, beach combing, boating, and sun bathing. Tourism contributes to the local economies of the three municipalities of Baclayon, Dauis and Panglao in terms of tourist spending, sales, income, tax revenues and employment. In 2003, there were close to 48,000 tourists visiting the BMT area (Table 5). During peak months from December to May, tourist visits average 5,506 tourists per month. Visitors decline by $50 \%$ or 2488 per month during lean months from June to November.

There are 17 coral reef diving destinations frequented by domestic and foreign tourists. Dive shops charge divers from US $\$ 23$ /dive to US $\$ 56$. On the average, a dive shop would cater to 390-1,980 divers per year totaling estimated gross revenue of US $\$ 10,500$ to US $\$ 45,540 /$ year. Tourists enjoying whale/dolphin tours comprise $32 \%$ of the total tourists. Whale and dolphin watching tourists increased from 1,008 tourists in 2002 to 2,781 tourists in 2004. Tourists' willingness-to-pay for whale and dolphin watching in Pamilacan Island, Bohol is US $\$ 3$ (Rosales, 2003).

Tourism revenues consist of indirect ${ }^{10}$ or private sector revenues from tourism-related business such as hotels, dive operations, whale/dolphin tours and restaurants. The average 
Table 6

Annual net benefits from tourism

\begin{tabular}{lcccr}
\hline & \multicolumn{4}{c}{ Annual Net Benefits from Tourism ${ }^{a}$ (US\$) } \\
\cline { 2 - 5 } Ecosystem & Baclayon $^{b}$ & Dauis & Panglao & \multicolumn{1}{c}{ BMT } \\
\hline Dive shop & & 34,907 & 423,242 & 458,149 \\
Boat operators & 14,722 & & & 14,722 \\
Hotel & & 150,000 & 687,556 & 837,556 \\
Restaurants & & 55,556 & 111,111 & 166,667 \\
Total & 14,722 & 240,462 & $1,221,909$ & $1,477,093$ \\
\hline
\end{tabular}

${ }^{a}$ Indirect or private sector net revenues from tourism are computed from the annual net revenue per entrepreneur and the number of entrepreneurs in the municipality.

${ }^{b}$ Pamilacan Island.

annual net revenues from tourism business total US $\$ 3,680$ for boat tour operators, US $\$ 19,308$ for dive shops, US $\$ 25,000$ for restaurants and US $\$ 24,278$ for hotel operators. The total annual net benefits from tourism are US $\$ 1.48$ million (Table 6). All revenue generated from tourism in the BMT area is dependent on the natural base either directly or indirectly. Direct net benefits from tourism comprise $32 \%$ and include revenues from diving activities, marine mammal watching, other beach activities such as swimming, snorkeling, boating. Indirect net benefits from tourism consist of revenues from restaurants and hotels. All tourism hotels and restaurants surveyed in this study were established on Panglao Island primarily for the aesthetic value of the natural resource base. ${ }^{11}$

\section{Research Values}

The BMT area continues to be a site for the conduct of scientific studies by local as well as foreign organizations. Research values are based on research expenditures. The cost of conducting studies reflects the willingness to pay for access to coral reef, beach and mangrove areas with research value. The research value of the BMT is estimated at US $\$ 9,259$ per research study per year. This value represents expenditures for field work, primary data gathering, boat/vessel rental, supplies, and some diving equipment. ${ }^{12}$ Conservatively, there will be one research expedition per year in the BMT.

\section{Indirect Use Values}

The indirect use values are in terms of ecological functions that the coastal and marine ecosystems provide. The coral reefs in the BMT are biologically diverse and serve as reservoirs of genetic variability. For mangroves, indirect use values include: (a) the control of coastal erosion or damage protection from storms, wave action and wind; (b) the provision of feeding, nursery and breeding areas for fish; and (c) biodiversity. Table 7 shows the benefits derived from indirect and option values of coral reefs and mangroves. For the nursery role function provided by mangroves for fish and shrimp, a conservative estimate of $25 \%$ of fish landings was used. ${ }^{13}$ For shoreline protection, the cost of constructing protective seawalls or dikes is used. Biodiversity for coral reefs are based on Arin and Kramer's (2002) study on average willingness-to-pay as a daily entrance fee to a marine sanctuary in Panglao Island, Bohol of US\$3-4 per individual per visit. Biodiversity for mangroves was based 
Table 7

Benefits from indirect and option values

\begin{tabular}{lccrr}
\hline & \multicolumn{3}{c}{ Benefits from indirect and option values (US\$/year) } \\
\cline { 2 - 5 } Resource function & Baclayon & Dauis & Panglao & BMT \\
\hline Coral reef & & & & \\
$\quad$ Biodiversity & & & & \\
Mangrove $_{\quad \text { Shoreline protection }}{ }^{b}$ & 15,236 & 55,628 & 50,162 & 121,027 \\
$\quad$ Habitat/nursery function & $c$ & & & \\
Biodiversity $^{d}$ & 5,913 & 29,127 & 134,635 & 169,674 \\
Total $^{c}$ & 163 & 10,537 & 48,707 & 61,383 \\
\hline
\end{tabular}

${ }^{a}$ Computed using diver's willingness-to-pay of $\$ 4$ on Alona Beach, Panglao, Bohol (Arin \& Kramer, 2002), and the number of divers during peak and lean months in the three municipalities.

${ }^{b}$ Replacement cost approach estimated at $\$ 532 /$ ha (Tridoyo, 1998).

${ }^{c}$ Nursery and habitat role estimated at $25 \%$ of fish landings. This is a conservative assumption based on 50\% fish catch landings attributed to mangrove nursery role for fish and shrimps (Sasekumar et al., 1998).

${ }^{d}$ Biodiversity value of $\$ 15 / \mathrm{ha} /$ year based on cost-benefit analysis of mangroves in Bintuni Bay, Indonesia (Ruitenbeek, 1992).

on the estimated benefits captured of $\$ 15 /$ ha/year (Ruitenbeek, 1992). ${ }^{14}$ These values were applied to the corresponding area (ha) of mangroves in the three municipalities in the BMT.

\section{Total Net Benefits}

The annual net benefits of the coastal and marine resources in the BMT is $\mathrm{PhP} 182.4$ million or US\$3.38 million (Table 8). Municipal fisheries and tourism are the major economic sectors generating direct use values from the BMT resources at US $\$ 1.33$ (39\%) and US $\$$ 1.48 million (44\%), respectively. The results of this valuation are compared to other studies (Table 9). In general, the actual net revenues derived from coral reefs and mangroves are within acceptable ranges.

\section{Discussion}

The annual net benefits of the coastal and marine resources of the BMT amount to $\mathrm{PhP} 182.4$ million or US $\$ 3.38$ million. Total annual net benefit is accounted for by net market or direct use values of US $\$ 2.99$ million (PhP 161.6 million), and non-market values of US $\$ 384,538$ ( $\mathrm{PhP} 20.7$ million). The main direct use value or market benefits of coastal resources are tourism and fisheries (Figure 4). The net revenues from tourism and fisheries are valued at US $\$ 1.48$ million (PhP 79.7 million) and US $\$ 1.33$ million (PhP 71.6 million), respectively. These values account for more than $70 \%$ of the net benefit of the BMT. Putting the net benefit of these marine resources into the context of economic activity in the Philippines, municipal fisheries is $0.22 \%$ of Philippine municipal fisheries (GDP of $\$ 613$ million in 2000 ) and $0.08 \%$ of Philippine tourism (GDP of $\$ 1,838$ million in 2000) (NSCB, 2002). 
Table 8

Total net benefits

\begin{tabular}{|c|c|c|c|}
\hline \multirow[b]{2}{*}{ ECOSYSTEM } & \multirow[b]{2}{*}{ Resource Use } & \multicolumn{2}{|c|}{ Annual net revenue } \\
\hline & & US\$ & US $\$$ per hectare \\
\hline \multirow[t]{6}{*}{ Coral reef } & DIRECT & & \\
\hline & Fisheries & 655,925 & $405-1,625$ \\
\hline & Tourism & 458,149 & $202-1,471$ \\
\hline & Research & 27,778 & $32-111$ \\
\hline & OPTION & & \\
\hline & Biodiversity & 121,027 & $166-319$ \\
\hline \multirow[t]{3}{*}{ Seagrass } & DIRECT & & \\
\hline & Fish & 58,846 & $8-84$ \\
\hline & $\begin{array}{l}\text { Mollusks / } \\
\text { Echinoderms }\end{array}$ & 47,144 & $12-120$ \\
\hline \multirow[t]{8}{*}{ Mangrove } & DIRECT & & \\
\hline & Fish & 3,236 & 16 \\
\hline & Mollusks/Echinoderms & 6,667 & 33 \\
\hline & INDIRECT & & \\
\hline & Nursery role & 61,383 & 243 \\
\hline & Erosion protection & 169,674 & 672 \\
\hline & OPTION & & \\
\hline & Biodiversity & 4,676 & 19 \\
\hline \multirow{4}{*}{$\begin{array}{l}\text { Beach/Intertidal } \\
\text { area }\end{array}$} & DIRECT & & \\
\hline & Mollusks/Echinoderms & 112,753 & \\
\hline & INDIRECT & & \\
\hline & Tourism & $1,004,222$ & \\
\hline \multirow[t]{4}{*}{ Marine waters } & DIRECT & & \\
\hline & Fisheries & 608,529 & \\
\hline & Seaweed Farming & 23,087 & 660 \\
\hline & Tourism & 14,722 & \\
\hline Total & & $3,377,818$ & \\
\hline
\end{tabular}

The most important non-market benefits that can be derived from coastal ecosystems are shoreline protection with annual values of US $\$ 169,674$ (PhP 9.1 million) and biodiversity value of US $\$ 125,703$ (PhP 6.7 million). These non-market benefits account for 9\% of the total net benefit of the BMT. Among the coastal and marine ecosystems, the coral reef and beach/intertidal areas yield the highest net value of US $\$ 1.26$ million ( $\mathrm{PhP} 68.1$ million) and US $\$ 1.12$ million (PhP 60.6 million), respectively, accounting for $70.6 \%$ of the total net benefits of the BMT (Figure 5). Marine waters, mangroves and seagrass resources account for $19.1 \%, 7.1 \%$, and $3.2 \%$ of the total annual value, respectively. Present value of the stream of net benefits from the coastal resources of BMT over a 10 -year period at $10 \%$ discount rate, amount to US $\$ 11.54$ million ( $\mathrm{PhP} 623.1$ million).

The BMT coastal ecosystems are capable of sustaining more than one economic activity at the same time. Multiple uses of coastal ecosystems provide more benefits than a single use. The current net benefits are dependent on the coastal and marine resources for these benefits 
Table 9

Comparison of benefits from BMT to other studies

\begin{tabular}{|c|c|c|c|}
\hline \multirow[b]{2}{*}{ Resource use } & \multirow{2}{*}{$\begin{array}{l}\text { This study: } \\
\text { Annual Net } \\
\text { Revenue } \\
(U S \$ / h a)\end{array}$} & \multicolumn{2}{|c|}{ Other studies $^{a}$} \\
\hline & & $\begin{array}{l}\text { Annual revenue } \\
\qquad(P h P / h a)\end{array}$ & Author, Year \\
\hline Coral Reefs & 2,228 & $319-1,130$ & $\begin{array}{l}\text { White, Vogt, and Arin } \\
\text { (2000) }\end{array}$ \\
\hline \multirow{5}{*}{ Fisheries } & 1,165 & 50-75 (Olango Island) & White et al. (2000) \\
\hline & & 156-463 (Philippines) & $\begin{array}{l}\text { White and } \\
\text { Cruz-Trinidad } \\
\text { (1998) }\end{array}$ \\
\hline & & 228 & Costanza et al. (1997) \\
\hline & & 518 (Apo Island) & $\begin{array}{l}\text { White, Vogt, and Arin } \\
\text { (2000) }\end{array}$ \\
\hline & & 81-102 (Sri Lanka) & Berg et al. (1998) \\
\hline \multirow[t]{4}{*}{ Tourism } & 835 & $\begin{array}{l}\text { 249-398 (Olango } \\
\text { Island) }\end{array}$ & White et al. (2000) \\
\hline & & 20-204 (Philippines) & $\begin{array}{l}\text { White and } \\
\text { Cruz-Trinidad } \\
\text { (1998) }\end{array}$ \\
\hline & & 3,119 & Costanza (1997) \\
\hline & & 1556 (Sri Lanka) & Berg et al. (1998) \\
\hline Research & 53 & - & - \\
\hline Biodiversity & 174 & $\begin{array}{l}\text { 24-83 } \\
\quad \text { (willingness-to-pay) }\end{array}$ & $\begin{array}{l}\text { White and } \\
\text { Cruz-Trinidad } \\
\text { (1998) }\end{array}$ \\
\hline Mangrove & 983 & 600 & $\begin{array}{l}\text { White and } \\
\text { Cruz-Trinidad } \\
\text { (1998) }\end{array}$ \\
\hline \multirow[t]{4}{*}{$\begin{array}{l}\text { Fisheries, } \\
\text { mollucs, and } \\
\text { echinoderms }\end{array}$} & 49 & 55 (Philippines) & $\begin{array}{l}\text { White and } \\
\text { Cruz-Trinidad } \\
\text { (1998) }\end{array}$ \\
\hline & & $\begin{array}{l}62 \text { (Pagbilao, } \\
\text { Philippines) }\end{array}$ & $\begin{array}{l}\text { Janssen and Padilla } \\
\text { (1999) }\end{array}$ \\
\hline & & 223 (Thailand) & Christensen (1982) \\
\hline & & 132 & Spurgeon (1998) \\
\hline $\begin{array}{l}\text { Erosion } \\
\quad \text { protection }\end{array}$ & 672 & 532 & Tridoyo (1998) \\
\hline Nursery/habitat & 243 & 176 & Costanza et al. (1989) \\
\hline Biodiversity & 19 & 21 & Spurgeon (1998) \\
\hline Seagrass & 76 & - & - \\
\hline Fisheries & 63 & - & - \\
\hline $\begin{array}{l}\text { Mollusks/ } \\
\text { Echinoderms }\end{array}$ & 13 & - & - \\
\hline
\end{tabular}

${ }^{a}$ For comparability, the net benefits cited from other studies as US $\$ / \mathrm{km}^{2}$ were converted to US $\$ / \mathrm{ha}$. 


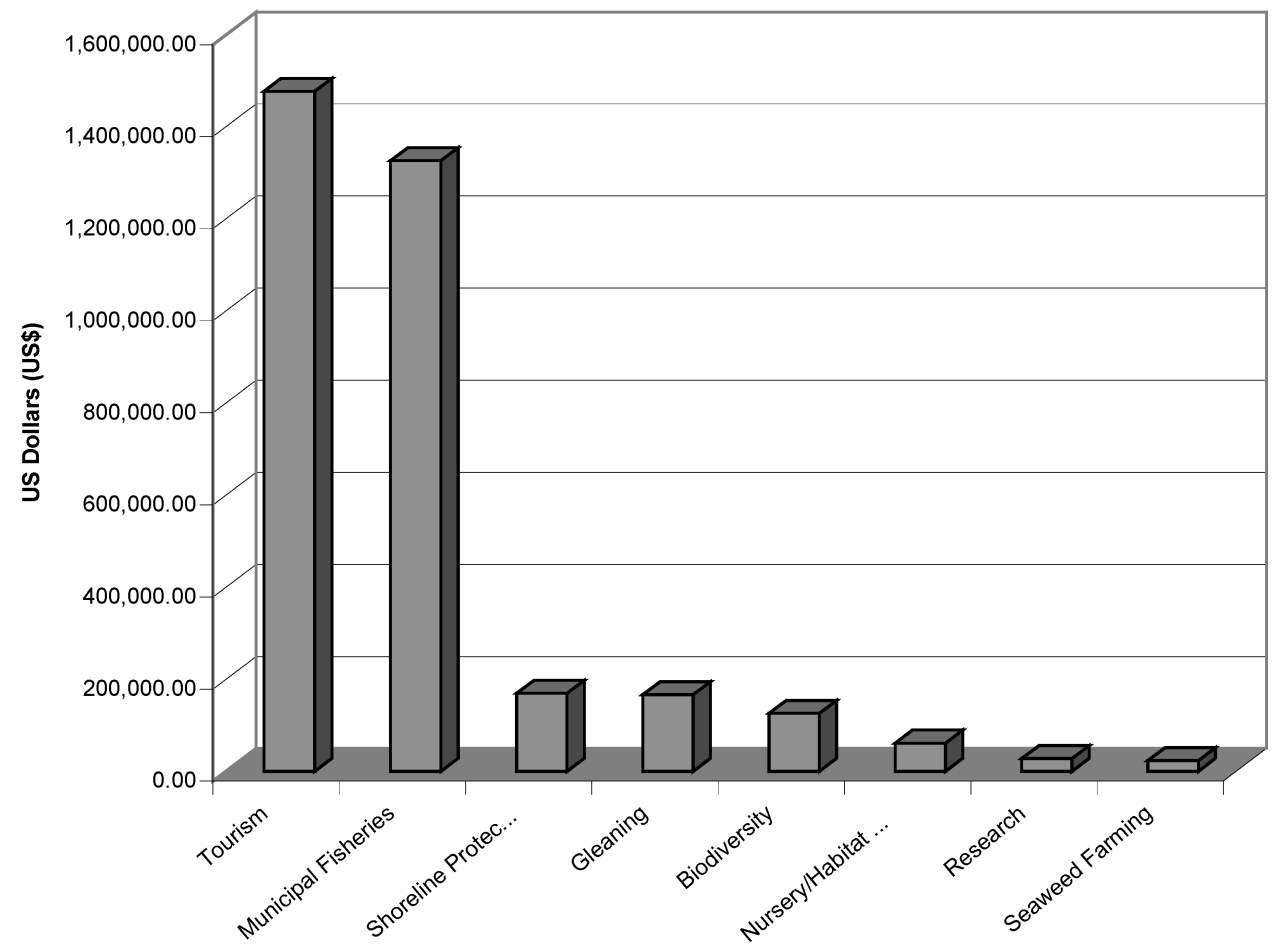

Figure 4. Use and non-use values of BMT coastal and marine resources per year.

to continue into the future. Efforts must be exerted to maintain the diversity, health and productivity of coastal and marine ecosystems to sustain these benefits. The stakeholders in the BMT area should effectively manage their coastal ecosystems as it is the foundation toward obtaining basic needs and improving the quality of life of coastal residents.

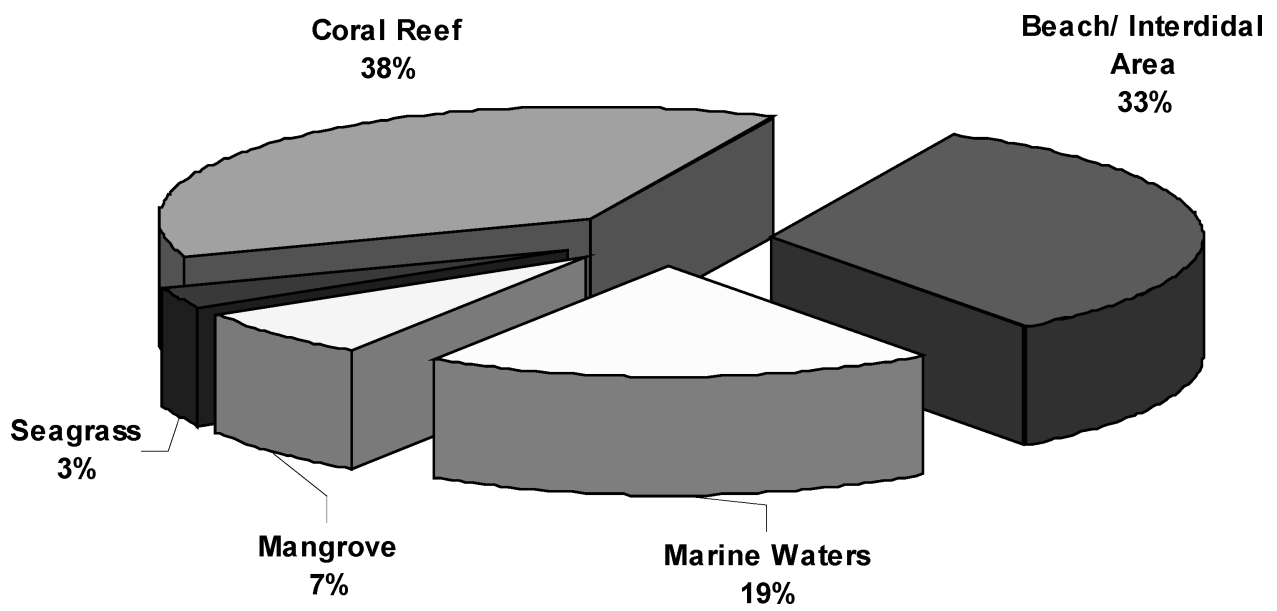

Figure 5. Net benefits of coastal and marine resources. 
In an effort of the local government and communities to protect coral reefs and sustain the fisheries twelve marine protected areas (MPAs) were established in the Bohol Marine Triangle (BMT) covering a total area of 160 ha. The MPAs are distributed in the BMT as follows: one in Baclayon, three in Dauis and eight in Panglao. The cost for managing these MPAs ranges from US $\$ 3,034$ to US $\$ 12,933$ (PhP 164,000-700,000) per year for MPA areas ranging from 3-70 hectares. Costs were mainly for implementing activities such as information dissemination and surveillance (60\%), community organizing (20\%), capacity building activities (10\%) and the remaining $10 \%$ for billboards and buoys. In 2003 , these costs comprised less than $2 \%$ of the annual budget of each local government unit in Baclayon, Dauis, Panglao. ${ }^{15}$ The current problem is the lack of funds for managing the MPAs- a major concern for most MPAs as it affects the enforcement efforts. In Baclayon, the Pamilacan Island Marine Sanctuary initiated mooring buoy fees of US $\$ 9 /$ boat (PhP $500)$ in 2003. Annual revenue generated from mooring fees is US $\$ 926$ ( $\mathrm{PhP} 50,000)$. In Panglao, only the Balicasag Island Marine Sanctuary derives revenue from mooring buoy fees of up to US $\$ 352$ per year ( $\mathrm{PhP} 19,000)$.

Managing coastal and marine resources will have impact on the local economy, in terms of income or value added. The revenue generated through the fishery sector goes directly into the local economy, and hence employment. The income to the municipality and to the Bohol province region is reflected in the wages, salaries, rents and profits generated by tourist spending. Value added is also revenue to local government units from taxes. The value added generated from the coastal and marine resources of the BMT are reflected in the income and indirect business taxes generated by the tourism sector. Tourism's employment effects are noticeable in the large number of part time and seasonal jobs associated with tourism in BMT area.

The pressure on the BMT coastal and marine resources can be intense in some areas as identified by the local residents, government and non-government organizations in the Bohol area. For example, in several workshops and focus group discussions held during the conduct of the study, key issues prioritized by all stakeholder groups included (CCEFI, 2004): (1) the over harvesting by gleaners and increasing number of gleaners leading to decrease in harvest per gleaner; (2) over fishing due to open access, intrusion of fishers from other towns and provinces, encroachment of commercial fishers; (3) increasing number of fishers; (4) use of illegal fishing methods (e. g., cyanide, gill/fine mesh nets); (5) unregulated expansion of coastal development for tourism; and, (6) land-based pollution. The intensity and diversity of demands placed on coastal ecosystems will continue to increase as population grows. The challenge is to ensure that these benefits derived from BMT coastal and marine resources are optimized now and into the future.

\section{Conclusion}

The economic valuation of the BMT has been incorporated in several management activities for the BMT area. First, the economic valuation results were expounded in communication strategies particularly in information, education and communication (IEC) materials. The benefits generated from the BMT are always emphasized during IEC activities and strategies with the purpose of informing the resident stakeholders to appreciate the economic value generated from the BMT. Second, the economic valuation was presented to the municipal governments of Baclayon, Dauis, and Panglao. The local government units have appreciated the economic valuation results and have considered the valuation in all management planning decisions in their respective municipalities, such as zonation 
planning and ecotourism planning. On a BMT-wide basis, the economic valuation was considered in the development of the 10-Year BMT Management Plan (2006-2015). The third application of the economic valuation is as a basis for the formulation of environmental user fee at the municipal level. For instance, user fees are currently being developed for the marine protected areas in Dauis and Panglao municipalities. Fourth, the economic valuation is used in policy advocacy for the conservation and protection of Panglao's natural resources. There is a recent plan to establish an international airport on Panglao Island. This BMT valuation is a very important document, which is being used by concerned stakeholders in the benefit-cost analysis of the impact of the upcoming plan to establish an international airport on Panglao Island. Fifth, the BMT valuation as a basis for planning interventions is considered a 'best practice' in Bohol Province and other conservation sites in the Philippines. The application of conducting economic valuation as a tool for policy and planning is currently being replicated in other coastal and marine areas. For example, the nearby Maribojoc Bay in Bohol, which covers five municipalities has replicated this process of conducting an economic valuation for input in the planning activities of the Fisheries and Aquatic Resources Management Council (FARMC). Similarly, the Dinagat Island conservation site in southern Philippines has also conducted a valuation of their coastal and marine resources for more informed decision-making against unsustainable livelihood practices.

The value of coastal and marine resources of the Bohol Marine Triangle is essential in policymaking as this information can be used in setting charges and in benefit-cost analysis of management interventions, programs and investments, which would have consequent impacts on the condition of these resources. Putting a value on the coastal and marine ecosystems of the Bohol Marine Triangle indicates to users and stakeholders that there are opportunity costs involved in using the resources. The resource valuation gives an indication to policymakers of how the resources can be allocated and the formulation of user fees to account for the environmental costs associated with the activities of users.

The different uses of the coastal resources in the Bohol marine triangle contribute net benefits to the residents of Baclayon, Dauis and Panglao. The establishment of MPAs for the protection and conservation of the marine resources entails both costs: (a) the opportunity cost of foregoing other socially valued uses such as fishing and recreation, and (b) the cost of additional resources required for ensuring that the ecosystems are actually being protected. It is therefore necessary to support the implementation of strategies and programs to protect the coastal and marine resources for net benefits to continue into the future.

\section{Notes}

1. Key focus interventions in the BMT include marine reserves, elimination of destructive activities, alternative livelihood development.

2. Issues and opportunities were identified and discussed during multi-sectoral consultation workshops held in July 2004 with participation/representation of local stakeholders including fishers, local government units, non-government organizations, relevant government agencies, and the tourism business operators.

3. The benefits transfer approach presents some methodological issues: 1) the transfer of non-market value results from one location to another requires considerable adaptation; 2) any uncertainty with the original stated-preference study is transferred to this study.

4. Municipal fishing is the sector of fisheries that includes catching of fish in marine waters within the fifteen kilometers shoreline limit with the use of fishing boat of three gross tons or less, or using gear not requiring the use of boats. 
5. US $\$ 1.00=\mathrm{PhP} 54.00$ (2004)

6. Among the fishing gears, nets yielded the highest catch ranging from $4.7-12.5 \mathrm{~kg} / \mathrm{trip}$ during peak fishing months. Spear fishing yielded the lowest catch averaging $1.4-4.6 \mathrm{~kg} / \mathrm{trip}$.

7. Opportunity cost of labor is assumed at $\mathrm{PhP} 80 /$ day (US $\$ 1.50 /$ day) based on provincial minimum wage rate in the Philippines. This was used for coastal activities including municipal fishing, gleaning, and seaweed farming, which use mainly family labor.

8. From intertidal area and seagrass beds, the gastropods and bivalves gleaned include pear oysters (Pterridae), miter shells (Mitridae), cockle (Cardiidae), venus shells (Veneridae), abalone (Haliotidae), bubble shells (Bullidae), Conches (Strombidae), Periwinkle (Littorinidae). Echinoderms gleaned include sea cucumbers (Holothuridae), sea urchins (Echinometra mathaei, Tripneustus gratilla and Diadema spp.).

9. Songculan Guso Farmers' Association (SOGUFA), Tabalong Seaweed Association and Panglao Seaweed Farmers' Association (PASFA).

10. No diver's fee is established in the BMT, hence potential direct revenues from diving are reflected in biodiversity value of coral reefs and based on diver's willingness-to-pay and number of divers.

11. Thus, although tourists have mixed motivations and there are many places they continue to visit, degraded natural resources in the BMT area will be unfavorable for the tourism establishments on Panglao Island.

12. Education and research value was estimated at $\$ 2.73 / \mathrm{ha} /$ year based on research expenditures, and expenditures on field courses, fellowships, training courses, education facilities and materials (Bunce et al., 1999).

13. Sasekumar et al. (1998) assumed that $50 \%$ of the fish landings could be attributed to mangroves. This off-site mangrove catch was valued for all the fisheries administrative districts on the west coast of Malaysia, Singapore and Indonesia.

14. Ruitenbeek (1992) discusses that historically, the 'capturable biodiversity benefit', defined as the potential benefit which the country might be able to obtain from the international community in exchange for maintaining its biodiversity base intact, was essentially zero. As the institutions and funds (e. g., USAID, international organizations, GEF) are becoming better established, countries can now capture some of the biodiversity benefit by attracting foreign funding for projects which promote conservation initiatives. In a benefit-cost analysis of Bintuni Bay, Indonesia, a value of US $\$ 1,500$ per square kilometer per year is ascribed as 'capturable biodiversity benefit' if the mangrove were maintained intact.

15. Approximately US $\$ 500.00$ in 2003.

\section{References}

Arin, T., and R. A. Kramer. 2002. Divers' willingness to pay to visit marine sanctuaries: an exploratory study. Ocean \& Coastal Management 45:171-183.

Bohol Environment Management Office. Municipal Coastal Database. 2000.

Bunce, L., K. Gustavson, J. Williams, and M. Miller. 1999. The human side of reef management: A case study analysis of the socioeconomic framework of Montego Bay Marine Park. Coral Reefs 1999:369-380.

Calumpong, H. P. ed. 2004. Profile of the Bohol Marine Triangle: Biodiversity Inventory and Assessment. Silliman University Marine Laboratory Dumaguete City. 208p.

CCEFI. 2004. Workshop Report on The Resources, The People, The Future: A Validation Workshop on the Resource Economic Valuation of the Bohol Marine Triangle, Bohol September 2, 2004, Coastal Conservation and Education Foundation, Inc., 27p.

Cesar, H., and C. K. Chong. 2004. Economic Valuation and Socioeconomics of Coral Reefs. Methodological Issues and Three Case Studies, p. 14-40. In Economic Valuation and Policy Priorities for Sustainable Management of Coral Reefs, eds. M. Ahmed, C. K. Chong, and H. Cesar, WorldFish Center Conference Proceedings 70, 222 p. 
Costanza, R., S. C. Farber, and J. Maxwell. 1989. Valuation and management of wetland ecosystems. Ecol. Econ. 1:335-361.

Foundation for Philippine Environment. 2000. Silliman University Marine Laboratory, Bohol Integrated Development Foundation, Sulu Fund for Marine Conservation Foundation and Coastal Resource Management Project. Biodiversity Conservation and Management of the Bohol Marine Triangle:34p.

Janssen, R., and J. E. Padilla. 1999. Preservation or Conversion? Valuation and Evaluation of a Mangrove Forest in the Philippines. Environmental and Resource Economics 14:297-331.

NSCB (National Statistical and Coordination Board). 2002. Philippine Statistical Yearbook. NSCB, Philippines.

NSCB (National Statistical and Coordination Board). 2003. Philippine Statistical Yearbook. NSCB, Philippines.

Rosales, R. P. 2003. A Survey to Estimate the Recreational Value of Selected MPAs: Moalboal-Cebu, Siquijor and Pamilacan Island-Bohol. Coastal Conservation Education Foundation, Inc, Cebu City, Philippines

Ruitenbeek, H. J. 1992. Mangrove management: An economic analysis of management options with focus on Bintuni Bay. Irian Jaya, Halifax, Nova Scotia: Dalhousie University.

Sasekumar, A., V. C. Chong, and S. M. Phang. 1998. Marine and Coastal Resource Valuation for the Straits of Malacca. University of Malaya. Report to the GEF/UNDP/IMO Regional Programme for the Prevention and Management of Marine Pollution in the East Asian Seas.

Spurgeon, J. P. 1992. The Economic Valuation of Coral Reefs. Marine Pollution Bulletin. 24(11):529536.

Spurgeon, J. 1998. Socio-economic Costs and Benefits of Coastal Habitat Rehabilitation and Creation. Marine Pollution Bulletin 37(8):373-382.

Tridoyo, K., S. Koeshendrajana, A. Fahrudin, and L. Adrianto. 1998. Cost-Benefit Analysis of Habitat Conservation in the Malacas Straits. Center for Coastal and Marine Resources Studies, Bogor Agricultural University.

White, A. T., and A. Cruz-Trinidad. 1998. The Value of Philippine Coastal Resources: Why Protection and Management are Critical, Cebu City, Philippines: Coastal Resources Management Project, $96 \mathrm{p}$.

White, A. T., M. Ross, and M. Flores. 2000. The Benefits and Costs of Coral Reef and Wetland Management, Olango, Island, Philippines, Cebu City, Philippines: Coastal Resource Management Project.

White, A. T., H. P. Vogt, and T. Arin. 2000. Philippine Coral Reefs Under Threat: The economic losses caused by reef destruction. Marine Pollution.Bulletin 40:598-605.

White, A. T., B. Stockwell, A. T. Meneses, S. Tesch, M. Ovenden, E. White, and J. Apurado. 2003. Summary field report: Coral reef monitoring surveys for conservation in Bohol and Siquijor. Earthwatch Expedition to the Philippines, Cebu City, Philippines: Coastal Conservation Education Foundation, Inc and Coastal Resource Management Plan. 